Anna Tyrpa

Instytut Języka Polskiego PAN, Kraków

annatyrpa@pro.onet.pl

\title{
STEREOTYPY ETNICZNE W RÓŻNYCH JĘZYKACH - NARODOWE? MIĘDZYNARODOWE? UNIWERSALNE?
}

\footnotetext{
Słowa klucze: stereotyp etniczny, frazeologia porównawcza, ksenonim, etnonim Keywords: ethnic stereotype, comparative phraseology, xenonym, ethnonym
}

Przedmiotem artykułu są stereotypy etniczne utrwalone w językach. Stereotyp rozumiem za Jerzym Bartmińskim i Jolantą Panasiuk (Bartmiński, Panasiuk 1993) szeroko, z uwzględnieniem zarówno składników poznawczych, jak i emocjonalnych. Autorzy ci podają aż sześć językowych wykładników stereotypizacji, spośród których w niniejszym artykule będą brane pod uwagę cztery: przenośne znaczenia wyrazów (np. niem. polak 'resztka tytoniu w fajce lub wina w kieliszku'), znaczenia jakościowe derywatów (np. franc. anglaiser 'kraść), frazeologizmy (np. czes. bílit mouřenína 'wykonywać na próżno jakąś robotę' i przysłowia (np. pol. Dla towarzystwa dał się Cygan powiesić).

Jednostki języka zawierające etnonimy lub toponimy (oraz ich pochodne), ale odnoszące się jedynie do cudzych, obcych narodów i krajów, Jelena Bieriezowicz (2006) nazywa ksenonimami. Wprowadza ona również termin ksenomotywacja - motywacja słów i frazeologizmów wynikająca z wyobrażeń o tym, co cudze, obce i ksenonominacja - tworzenie słów i frazeologizmów opartych na tych właśnie wyobrażeniach.

Artykuł będzie próbą zbliżenia się do odpowiedzi na pytania postawione w tytule. Czy takie jednostki leksykalne mają charakter narodowy, to znaczy pojawiają się 
indywidualnie w poszczególnych językach, czy są internacjonalizmami, czy może wręcz należą do uniwersaliów językowych?

Wiele światła na to zagadnienie rzucił W.M. Mokijenko (2007). W obszernym artykule na temat językowego obrazu świata w zwierciadle frazeologii udowodnił, że złudne jest mniemanie o odrębnych obrazach świata poszczególnych narodów, odbitych we frazeologii ich języków. Porównywanie ze sobą analogicznych frazeologizmów z języków europejskich ujawnia więcej zbieżności niż różnic. Autor stawia tezę, że główny zrąb frazeologii ukształtował się jeszcze w średniowieczu i podobny ustrój społeczny (feudalizm) wpłynął na podobne widzenie świata odbite w warstwie frazeologicznej wielu języków. Mokijenko skłania się raczej do mówienia o frazeologizmach międzynarodowych, a nawet uniwersalnych, niż do szukania w nich ducha poszczególnych narodów.

Aleksandra Niewiara, kończąc swój artykuł o polskich stereotypach narodowych w ujęciu diachronicznym, podkreśliła wagę badań porównawczych w tym zakresie:

Najpoważniejszym, najtrudniejszym też chyba zadaniem jest przeprowadzenie badań komparatywnych. Jeśli traktujemy stereotypy narodowe jako konstrukty kulturowe, to warto by sprawdzić, jak tworzy się je w innych kulturach: niemieckiej, francuskiej etc. Dopiero porównanie ich z polskimi sprawi, że dowiemy się czegoś naprawdę istotnego na temat nas samych, bo zdobędziemy wiedzę na temat „różnicy”, tego, co nas wyróżnia pośród innych narodów, a więc świadczy o jakości naszego istnienia co najmniej w Europie. Dopiero wtedy też inspiracje, które polskim badaczom zaoferował Jan Stanisław Bystroń, znajdą w pełni rozwinięcie (Niewiara 2010: 181).

$\mathrm{Z}$ tej wypowiedzi wynika, że konfrontacja materiału z własnego języka z materiałem $z$ innych języków ma walor poznawczy nie tylko wobec tych obcych języków (i narodów posługujących się nimi), ale też wobec własnego języka (i narodu).

Językowe stereotypy dotyczące innych narodów są często wyrażane frazeologizmami. Dlatego warto w tym miejscu wspomnieć o pracach Joanny Szerszunowicz, zajmującej się komparatystyką frazeologiczną. W jednym ze swych artykułów (Szerszunowicz 2004) autorka zaproponowała następującą klasyfikację paralelizmów frazeologicznych w różnych językach: 1. pochodzące $\mathrm{z}$ wspólnego dziedzictwa kulturowego (Biblia, mitologia, historia), 2. stanowiące zapis podobnych obserwacji rzeczywistości w poszczególnych kulturach (np. zachowania zwierząt), 3. powstałe w wyniku zapożyczeń, 4. pozorne (wspólna forma, różne znaczenia). Klasyfikację tę można by zastosować do interesujących nas frazeologizmów z etnonimami (lub ich pochodnymi), ale nie jest to takie proste. Ustalenie, jakim sposobem każda jednostka znalazła się w danym języku, wymaga drobiazgowych, szczegółowych badań. Dalej postaram się pokazać trudności, z jakimi borykają się badacze tej interesującej, ale skomplikowanej materii.

Zajmijmy się najpierw pierwszym pytaniem. Czy istnieją wyrazy i frazeologizmy odnoszące się do obcych narodów występujące tylko w jednym języku? Czy można $\mathrm{z}$ całą pewnością stwierdzić, że jakiegoś słowa lub frazemu nie ma w konkretnym 
języku? Od początku lat 9o. XX w. badania stereotypów narodowych bardzo się rozwinęły ${ }^{1}$, ale nikt nie jest w stanie poznać wszystkich jednostek leksykalnych danego języka. Oprócz odmiany standardowej istnieją dialekty i socjolekty. A jeśli weźmie się pod uwagę dawne epoki, to bogactwo materiału jest nieprzebrane.

Niektórzy autorzy zestawiają dane z dwóch języków i ustalają, które ksenonimy są właściwe tylko jednemu z nich. Tak postąpiły na przykład polskie lingwistki Elżbieta Michow (1994), porównując frazeologizmy polskie i bułgarskie, oraz Teresa Zofia Orłoś (1994) - polskie i czeskie. Obie badaczki nie ustrzegły się błędów. E. Michow uznała, że bułgarskie żartobliwe wyrażenie ewrejski westnik (żydowska gazeta) o znaczeniu 'pestki dyni' nie ma odpowiednika polskiego i wyraża cechę „brak uczoności (związane z ironicznym twierdzeniem, że zjadanie pestek dyni zastępuje Żydom czytanie gazet)" (Michow 1994: 63). Tymczasem w polskiej gwarze spiskiej zanotowano, że cytać zydowskom gazete znaczy 'wyjmować ziarenka z kwiatu słonecznika, a następnie je jeść' (SSWG 30). Oba frazemy są bardzo podobne - w planie wyrażenia (żydowska gazeta) i w planie treści (pestki dyni i ziarna słonecznika jako przekąska). Co do komentarza Michow, to nie wydaje się on słuszny. Ortodoksyjni Żydzi już w wieku lat trzech rozpoczynają naukę czytania po hebrajsku, więc uczoności im nie brakuje. Podczas międzynarodowej konferencji „Etnolingwistyka. Onomastyka. Etymologia” w Rosji (Czusowaja, 8-10 IX 2012) Jelena Bieriezowicz dodała w dyskusji, że w języku rosyjskim istnieje wyrażenie jewrejska gazeta, oznaczające pewien kamień szlachetny o żółtych żyłkach na czarnym tle. Według etnolingwistki z Jekaterynburga kamień ten wyglądem przypomina kwiat słonecznika, z którego wybrano już część ziaren (byłoby to nawiązanie do zwrotu z polskiego Spisza). Tajemnicą na razie pozostaje motywacja tych frazemów (czy może pestki i ziarna sprzedawali kiedyś Żydzi zawinięte w gazetę?) oraz okoliczności, w jakich podobna jednostka znalazła się w oddalonych od siebie języku bułgarskim, polskiej gwarze i języku rosyjskim.

Z kolei T. Z. Orłoś uznała kilka jednostek czeskich za idiomy, niemające polskich odpowiedników, podczas gdy dokładniejsze poszukiwania ujawniają, że takie odpowiedniki są: zdráv jako Turek (Orłoś 1994: 146) i zdrów jak Turek w gwarze kociewskiej (KSGP); zdravý jako Rus (Orłoś 1994: 145) i zdrów jak Rusek w gwarze kaszubskiej (S IV 369); zdrowy jak Rusek w gwarze kociewskiej (Pająkowska-Kensik 2009: 145); bílit mouřenína 'wykonywać na próżno jakąś robotę’ i Murzyna bielić (NK II 552).

Wygląda na to, że bezpieczniej w podobnych wypadkach pisać, że się nie znalazło odpowiedników w innych językach, a nie - że ich nie ma. Wniosek z tego jest taki, że może istnieją jednostki leksykalne odnoszące się do innych narodów tylko w jednym języku, ale takie twierdzenie wymagałoby sprawdzenia we wszystkich innych językach, co wydaje się niewykonalne.

1 Bogatą literaturę przedmiotu można znaleźć w książkach: Березович 2007 i Tyrpa 2011 (tu również omówienie prac porównawczych dotyczących stereotypów narodowych w różnych językach, S. 20-21). 
Przejdźmy teraz do drugiego pytania: czy w różnych językach zostały utrwalone stereotypy narodów o charakterze międzynarodowym? Jeśli ktoś zapozna się z odpowiednim materiałem leksykalnym czy przysłowiami tylko w jednym języku, to może sądzić, że mówiący tym językiem ludzie wytworzyli zbiór unikalnych spostrzeżeń na temat cudzoziemców. Ale jeśli sięgnie po analogiczne zbiory zapisane w innych językach zdziwi się, widząc wiele podobieństw (por. Tyrpa, Zieliński 2003). Przywołajmy słowa polskiego historyka, który opracował wzajemne postrzeganie Polaków i Niemców:

Moim zdaniem, opinii Niemców o Polakach nie należy traktować jako czegoś wyjątkowego, gdyż są one przejawem powszechnego zjawiska, które określa się mianem uprzedzeń narodowych, funkcjonujących w ludzkiej świadomości, owych stereotypowych, zazwyczaj negatywnych, wyobrażeń o przedstawicielach innego narodu czy grupy etnicznej. Źle i złośliwie wyrażali się Niemcy nie tylko o Polakach, ale także o Czechach i Francuzach, ci ostatni krytycznie patrzyli na Niemców i Anglików, Polacy, wykpiwani przez Niemców, drwili z Czechów, traktowani zaś przez Niemców z wyższością, własne kompleksy rozładowywali pogardliwym stosunkiem do Rosjan, Ukraińców i Białorusinów (Szarota 1996: 65).

Wiele cennych spostrzeżeń na temat międzynarodowych podobieństw ksenonimów przyniosły autorskie prace Bieriezowicz $(2005,2006,2007)$ i wspólna z Julią Kriwoszapową (2006). Liczne opracowania związane z tym tematem pozwalają zestawiać analogiczne jednostki z różnych języków, głównie indoeuropejskich, choć Bieriezowicz sięga również po przykłady z języków ugrofińskich². Paralelne leksemy i frazemy z kilku języków można rozpatrywać na dwóch planach: wyrażenia i treści. Oczywiście kluczowy tu jest plan treści, bo to właśnie znaczenie decyduje o uznaniu jednostek za ekwiwalentne. Wspólnemu znaczeniu towarzyszy czasem wspólny sposób wyrażenia, a czasem nieco odmienny (zawierający odesłanie do innego narodu). Badacz zadaje sobie pytanie: jak doszło do zaistnienia w różnych językach tak podobnych faktów językowych? Czy to kalki, czy efekt podobnego widzenia świata?

Rozpatrzmy kilka przykładów.

Jeśli w kilku językach znajdujemy wyrażenie o znaczeniu 'przedstawiciel ginącej rasy, zawodu, epigon': pol. ostatni Mohikanin, bułg. paslednijat mohikan, niem. der letzte Mohikaner, to wiemy, że pochodzi ono z powieści amerykańskiego pisarza Jamesa Fenimore’a Coopera pod tym samym tytułem³ ${ }^{3}$ Nie musimy się zastanawiać nad jego

2 W pracach słowackiego lingwisty L’ubora Králika można znaleźć przykłady węgierskie analogiczne do słowiańskich, dowodzące istnienia jedności kulturowej między językami należącymi do różnych rodzin językowych (por. np. Кралик 2006). J. Szerszunowicz (2004: 208) pisze, że języki fiński i węgierski współtworzą wraz z indoeuropejskimi językami Europy europejską ligę językową.

3 Powieść ta, stanowiąca drugi tom cyklu Pięcioksiag przygód Sokolego Oka, ukazała się w roku 1826 pod tytułem The last of the Mohicans. Już w 1830 r. polscy czytelnicy dostali jej pierwszy przekład z tytułem Ostatni z Mohikanów. W następnych przekładach (np. z 1896) utrwalił się tytuł Ostatni Mohikanin (NK II 516 i Internet). 
motywacją, choć i tak nie jest pewne, czy w każdym języku zjawiło się ono niezależnie, na skutek lektury powieści Ostatni Mohikanin, czy może przyswojone jako skrzydlate słowo w jednym języku - zostało skalkowane w innych. Do ustalenia tego trzeba by przynajmniej poznać czas pojawienia się frazemu w każdym języku i porównać z czasem ukazania się przekładów amerykańskiej powieści na języki narodowe.

Jeśli w języku francuskim wyrażenie frères siamois (bracia syjamscy) ma dwa znaczenia: 1. 'bliźnięta zrośnięte ze sobą i 2. 'nierozłączni przyjaciele', to można sądzić, że polskie analogiczne bracia syjamscy jest kalką z francuskiego, zwłaszcza, jeśli się pamięta o znacznym wpływie frazeologii francuskiej na frazeologię polską (Damborský 1969).

Kolejny przykład to zwrot o znaczeniu 'wyjść, opuścić towarzystwo bez pożegnania'. Zwrot ten występuje w licznych językach, a ciekawe są jego warianty w planie wyrażenia (odwołania do różnych narodów) i w planie treści (wartościowanie pozytywne lub negatywne). W języku francuskim oraz w słowiańskich w zwrocie tym używa się przysłówka po angielsku: franc. filer à l'anglaise, pol. wyjść po angielsku, słowac. anglicky zmiznút', ros. yŭти по-английски, bułg. izmykwam se / izmykna se po anglijski. W językach angielskim, niemieckim i hiszpańskim - po francusku: ang. to take French leave, niem. sich auf französich empfehlen, hiszp. se despidió a la francesa. Dodatkowo w jednym z niemieckich słowników zapisano polnischer Abschied (polskie pożegnanie). Co do oceny takiego postępowania, to w czterech językach jest ono potępione. Na temat polnischer Abschied słownik podaje: „odejść z polskim pożegnaniem, bez pożegnania, albo pozostawiwszy długi odejść w milczeniu" (Szarota 1996: 73). Również warianty rosyjski, bułgarski i francuski mają przypisaną wartość ujemną. Bieriezowicz (2006: 14) wymienia go jako przykład „неэтикетного поведения”. Autorki kolejnych opracowań podkreślają różnicę między uznawaniem takiego zachowania za naganne przez Bułgarów i Francuzów, a za właściwe - przez Polaków. Według nich wpływa na to wyobrażenie o Anglikach (negatywne u Francuzów, pozytywne u Polaków). Bułgarski zwrot wyjaśniony jest tak: „'wychodzę bez pożegnania, zwykle, aby uniknąć jakichś zobowiązań. Jeśli polski stereotyp zawiera przekonanie o takcie i dyskrecji Anglików, to bułgarski - przeciwnie - sygnalizuje brak taktu i kultury osobistej (zawierając odcień dezaprobaty dla takiego sposobu postępowania)" (Michow 1994: 65). Francuska badaczka stereotypów pisze:

Znane powszechnie powiedzenie à l'anglaise ('po angielsku') w XIX w. było rozumiane jako 'gwałtowne, niegrzeczne wyjście cichaczem', podobnie zresztą jak używana do dziś forma kolokwialna pisser à l'anglaise ('wysiusiać się po angielsku'), którą można sparafrazować: 'wyjść po cichu, ulotnić się w decydującym momencie, by nie stawiać czoła trudnościom'. Wyrażenia te, modyfikowane leksykalnie za pomocą różnych form ( filer) partir/s'en aller/se sauver à l'anglaise), implikują tchórzliwość i brak manier, typowe, w odczuciu Francuzów, dla Anglików. Inaczej niż w języku polskim, gdzie wyjść po angielsku, oznacza 'zachować się jak Anglik', tzn. 'elegancko, dyskretnie' (Pelletier 1998: 243).

Powyższe interpretacje ujawniają więź między planem wyrażania (stosunek do Anglików) i planem treści (pozytywna lub negatywna ocena zachowania im 
przypisywanego). Natomiast Björn Hansen (2006), rozpatrując te same przykłady, twierdzi, że te znaczenia motywacyjne nie przekładają się na realne postrzeganie Anglików (przez Polaków czy Rosjan) oraz Francuzów (przez Hiszpanów czy Anglików). Być może jednak w chwili powstawania poszczególnych wariantów tego zwrotu, wyobrażenia o Anglikach, Francuzach czy Polakach były żywe. Przypadek omawianego tu zwrotu dowodzi, że samo stwierdzenie międzynarodowego charakteru jednostki leksykalnej z komponentem etnicznym nie wystarcza. Bliższe przyjrzenie się jej ujawnia różne niuanse.

Leksykograf, zetknąwszy się z pojedynczym, niezrozumiałym dla siebie faktem językowym, usiłuje go jakoś wytłumaczyć. Tak czyni autor jednego z regionalnych słowników niemieckich, chcąc wyjaśnić, dlaczego resztkę wina na dnie kieliszka i resztkę tytoniu w fajce nazywa się polak. Pisze on, że

[...] kiedyś palenie tytoniu bądź było w Polsce mało, bądź w ogóle nie znane, a ci, którzy próbowali palić, nie wypalali tytoniu z fajki do końca. Użycie tego wyrazu potem zostało przeniesione na resztkę wina (Szarota 1996: 77).

Oczywiście nie jest to właściwa motywacja. U Polaków na Litwie z końcem XIX w. zanotowano w znaczeniu 'zawiesina w fajce' wyrażenie cygański marcepan (K I 265). Trzeba by znów, naśladując niemieckiego słownikarza, badać sposób palenia tytoniu przez Cyganów. Możliwa jest też taka interpretacja: Cyganie są tak biedni, że resztka tytoniu ma dla nich taką wartość, jak dla innych (Polaków) - marcepan. Tomasz Szarota stwierdził istnienie obu znaczeń (resztka tytoniu i resztka wina) dla wyrazów pochodnych od etnonimu Polak $\mathrm{w}$ wielu niemieckich słownikach i sam zaproponował trafną interpretację: „Czyżby i tu odnaleźć można uszczypliwość wobec Polaków, skoro fusy każdemu kojarzą się z czymś złym i niedobrym, co należy wyrzucić?" (Szarota 1996: 77). Badania Bieriezowicz (2006: 11) dowiodły, że niemieckie przykłady realizują międzynarodowy schemat, w którym etnonimami nazywa się resztki, odpady, produkty uboczne, takie jak plewy przy młócce, skwarki przy topieniu słoniny, odpryski metali przy ich wytapianiu ${ }^{4}$. Tak więc, im bogatszym materiałem $\mathrm{z}$ wielu języków dysponujemy, tym większe są szanse na odkrycie prawdziwej motywacji nominacyjnej.

Niektóre ksenonimiczne międzynarodowe frazemy realizują ogólny wspólny wzorzec, ale wypełniony odmiennymi elementami. Tak jest w wypadku znaczenia 'nigdy coś nie nastąpi', werbalizowanego według schematu 'stanie się to, gdy naród wyznający daną wiarę weźmie udział w obrzędach innego wyznania’. A więc Żydom przypisuje się zachowania katolików: kasz. na żydowskie Trzy Króle (S II 256); bułg. koga se wyrnat czifutite ot bożi grob (kiedy Żydzi wrócą od Bożego grobu) lub muzułmanów: bułg. koga si dojdat ewreite ot chadżiłyk (kiedy dojdą Żydzi z hadżdż - pielgrzymki

4 Również J. Szerszunowicz (2004) zauważa modele semantyczne frazeologizmów, które w różnych językach są wypełnione rozmaitymi elementami leksykalnymi. 
do Mekki) (Michow 1994: 62). Polskie wyrażenie łączy z muzułmanami nabożeństwo katolickie: jutro o tej porze, po tureckim nieszporze.

Znaczenie 'dawno temu' może być wyrażane przez wspomnienie odległych w czasie wydarzeń, związanych z obcym narodem. Dla Bułgarów są to Rosjanie: ostanało ot moskoweca. E. Michow (1994: 67) wyjaśnia, że fraza „odwołuje się do czasów, kiedy Bułgaria została wyzwolona [od Turków] przez Rosjan w końcu XIX wieku”. Również w języku rosyjskim wspomina się wojny z Turkami: когда турки воевали. Słowacy w XVII w. używali określenia przed Tatarami, nawiązując do napadów tatarskich z XIII w. (Králik 2006: 163). Polacy, chcąc powiedzieć, że coś działo się dawno temu lub jest bardzo stare (pamięta odległe czasy), wspominają wojny szwedzkie z XVII i XVIII w.: jak byly Szwedy; po starych Szwedach (NK III 418). Polskie gwary są matecznikiem podobnych frazemów, będących realizacją skryptu „Wojny szwedzkie były dawno temu" (Tyrpa 2011: 209).

Znane w Polsce w dwóch wersjach przysłowie o wzajemnej animozji Polaków i Niemców: Póki świat światem, nie będzie Niemiec Polakowi bratem; Jak świat światem, nie będzie Polak Niemcowi bratem ma swoje polskie warianty z innymi nacjami: Jak szwiat szwiatem, Polak ani Niemcowi, ani Moszkalowi nie będzie bratem; Nie będzie jako świat światem, Rusin Polakowi bratem; Póki świat światem, nie będzie Polak $z$ Turkiem bratem ${ }^{5}$ (NK II 1009). Ma ono też swoją wersję ruską: Poka swiat stoit swiatom, Russkij polaku nie budiet bratom, która żyje (według autora publikacji z 1867 r.) „we wszystkich narzeczach plemienia rosyjskiego, od Dniepru aż do Karpat" (Kępiński 1990: 162). Możemy się domyślać, że pierwotna postać była polska, ale trzeba by tego dowieść.

Czasem sama forma użyta we frazeologizmie podpowiada kierunek jego wędrówki z języka do języka. Widzimy to w wypadku niem. zwrotu leben wie Gott in Frankreich, który w dawnej czeszczyźnie brzmiał mít se / žit jak pánbůh ve Frankrajchu (Treder 1996: 132). Postać choronimu użytego w języku czeskim wskazuje na niemieckie źródło ${ }^{6}$. Zwrot ten notowano też w polszczyźnie: żyje jak Pan Bóg we Francji ‘̇̇yje rozkosznie, nie żałuje sobie, używa świata' (NK I 577) i w kaszubskim mieć so / žëc jak Pón Bóg we Francëji (Treder 1996: 132).

W dwóch odległych językach - rumuńskim i polskim (konkretnie - w gwarze $\mathrm{z}$ okolic Sieradza) znajdujemy zaskakująco podobne frazy. Łączy je funkcja pragmatyczna - służą do uspokojenia rozmówcy, zachęcają do porzucenia pośpiechu i niepokoju. W rumuńskim jest to ča (doar) nu dau (vin) turcii (przecież nie nadciągają Turcy), a w polskim Pij mleko, ruskie wojsko daleko (KSGP). Narody niepokojone przez obce wojska musiały żyć w napięciu, obawiając się najeźdźców. Dla Rumunów byli to Turcy, dla Polaków - Rosjanie.

5 Julian Krzyżanowski (1975: II 201) przypuszcza, że pojawienie się w tej wersji ze Śląska pruskiego słowa Turek jest eufemizmem (dla uniknięcia słowa Niemiec).

6 Nie zapominamy też o dużym wpływie frazeologii niemieckiej na czeską (Damborský 1969). 
Również jakieś trudne przeżycia stały się podstawą bułgarskiej frazy preripnał sym arabskoto w znaczeniu 'przeżyłem, przetrwałem to, co najbardziej męczące, najcięższe' (Michow 1994: 68), a starszym Polakom przypominają się słowa piosenki śpiewanej w czasach PRL: „Przeżyliśmy potop szwedzki, przeżyjemy i radziecki”.

W niektórych przypadkach jedne odpowiedniki różnojęzyczne wskazują na ten sam naród, a inne - na inny. Tak jest przy wyrażaniu znaczenia 'kraść, kradzież'. W języku polskim: cygańskie kupno (NK I 345); w gwarach polskich i kaszubskich skrypt „Cyganie kradną” jest realizowany przez cały szereg leksemów i frazemów (Tyrpa 2011: 76-77). W czeskim potocznym: krást jak cihán, a w niemieckim stehlen wie ein Zigeuner (Treder 1996: 138). Okazuje się jednak, że Cyganie nie są jedynym narodem, któremu przypisuje się złodziejstwo. W języku niemieckim funkcjonuje obok powyższego zwrot englisch einkaufen, a we francuskim czasownik anglaiser (Pelletier 1998: 244), które wskazują Anglików jako sprawców kradzieży.

Przy porównywaniu frazemów $\mathrm{z}$ etnonimami w różnych językach można się zetknąć z sytuacją, w której w jednym języku etnonim nie występuje, a w ekwiwalencie innojęzycznym - tak. Takie przypadki opisuje Julian Krzyżanowski (1975: I 140-146, II 326). Otóż w łacińskim dziele angielskiego dominikanina z XIV w. zapisano zdanie: Tales enim fatuo assimilantur, qui cum latronibus ad suspendium, ratione societatis properabat. (Podobni są do głuptaka, który dla towarzystwa poszedł z łotrami na szubienicę). W kolejnych polskich odpowiednikach tego przysłowia w miejsce głuptaka pojawiają się: Niemiec, Rusin i w końcu Cygan, i ta ostatnia wersja (Dla towarzystwa dał się Cygan powiesić) jest żywa w polszczyźnie do dziś. Drugi przykład to przysłowie angielskie $A$ hungry man an angry man (człowiek głodny bywa zły), którego polskie ekwiwalenty zawierają szereg etnonimów: Polak, gdy głodny, to zły, Francuz gwiżdże, a Włoch śpiewa; Gdy Polak głodny, świszcze, a Rusin żonę bije; Polak, gdy głodny, to $z \nmid y$. Trzeci przykład to para: niem. Lügenvater (ojciec kłamstwa) 'diabeł’ i kaszubskie ojc cëgónów (Treder 1996: 141). Wszystkie one wskazują na to, że wersje etnonimiczne nie powstały w wyniku bezpośrednich obserwacji zachowań przedstawicieli poszczególnych narodów. Są to wersje wtórne.

Wszystkie przywołane przykłady międzynarodowych paralel dowodzą, że wiele językowo utrwalonych stereotypów narodowych nie ogranicza się do jednego języka. Podobne doświadczenia historyczne doprowadziły do powstania podobnych jednostek. Niektóre z nich są zapewne kalkami. Ta gałąź leksykologii, frazeologii, dialektologii i historii języka wymaga wielu jeszcze studiów, zwłaszcza w aspekcie porównawczym, z uwzględnieniem materiału z jak największej liczby języków. I zalecana jest daleko posunięta ostrożność. Bez sprawdzenia wielu faktów, porównania czasu pojawiania się jednostek - trzeba się powstrzymać od ferowania wyroków.

I w końcu - trzecie pytanie: czy językowe stereotypy etniczne można zaliczyć do językowych uniwersaliów? Za cechy uniwersalne uznaje się takie cechy, które występują we wszystkich językach świata. Żeby to stwierdzić, należałoby zbadać pod tym kątem wszystkie języki świata. Na razie można tylko powiedzieć, że we wszystkich 
zbadanych pod tym kątem językach istnieją słowa i frazemy ksenonimiczne. Najlepiej pod tym kątem znane są języki indoeuropejskie. Wyrywkowe kwerendy Bieriezowicz pokazały, że w językach ugrofińskich też są one obecne, a nawet zachodzi międzyjęzykowa wędrówka pewnych jednostek leksykalnych. Należałoby dotrzeć do analogicznych prac orientalistycznych lub opracowań innych języków nieindoeuropejskich. Intuicja podpowiada, że wszystkie plemiona, ludy i narody stykają się z cudzoziemcami, więc też zapewne o nich myślą i mówią. Byłoby bardzo pouczające dowiedzieć się, jak i co mówią. Wtedy można by określić, na ile ksenonominacja jest zjawiskiem uniwersalnym.

\section{Literatura}

Bartmiński J., Panasiuk J., 1993, Stereotypy językowe, [w:] Encyklopedia kultury polskiej XX wieku, t. 2: J. Bartmiński (red.), Współczesny język polski, Wrocław, s. 363-387.

BIERIEZOWICZ JE., 2005, [= Е. Березович], «Чужие земли» в русском народном языковом сознании: прагматический аспект, „Вопросы ономастики” 2, s. 70-85.

Bieriezowicz Je., 2006, [= Е. Березович], О явлении лексической ксеномотивации, „Вопросы языкознания” 6, s. 3-20.

Bieriezowicz Jе., 2007, [= Е. Березович], Язык и традиционная культура. Этнолингвистические исследования, Москва.

Bieriezowicz Je., Kriwoszapowa Ju., 2006, [= Е. Березович, Ю. КривОщАПовА], Этнонимическая модель в славянских названиях насекомых, [w:] I. Janyšková, H. Karliková (red.), Studia etymologica brunensia, Praha, s. 17-33.

DAMвоRSкÝ J., 1969, Frazeologia czeska i polska w ujęciu porównawczym, „Język Polski” XLIX, s. 341-350.

HANSEN B., 2006, Экономные как немцы. Национальные стереотипы и их отражение в коннотациях этнонимов в русском и других языках, „Acta Neophilologica” VIII, s. 163-173.

K: J. Karłowicz, Słownik gwar polskich, t. I - VI, Kraków 1900-1911.

KęPIŃski A., 1990, Lach i Moskal. Z dziejów stereotypu, Warszawa - Kraków.

KRÁLIK L., 2006, [= Л. КрАлUк], Из словацкой диалектной лексики: deethnonyтіса, [w:] Ad fontes verborum. Исследования по этимологии и исторической семантике. К то-летию Жанны Жановны Варбот, Москва.

KrZYŻAnOwski J., 1975, Mądrej głowie dość dwie słowie. Pięć centuryj przysłów polskich i diabelski tuzin, t. I-III, Warszawa.

KSGP: Kartoteka Słownika gwar polskich w Instytucie Języka Polskiego PAN, Kraków.

Michow E., 1994, Międzynarodowe stereotypy narodowości (na podstawie frazeologizmów polskich i bułgarskich), „Kieleckie Studia Filologiczne” 7, s. 55-69.

Moкijenко W. M. [= В. М. Мокиенко], 2007, Языковая картина мира в зеркале фразеологии, [w:] W. Chlebda (red.), Frazeologia a językowe obrazy świata przełomu wieków, Opole, s. 49-66.

Niewiara A., 2010, Polskie stereotypy narodowe w świetle badań diachronicznych, „LingVaria” nr 2 (10), s. 171-183.

NK: J. Krzyżanowski, S. Świrko (red.), Nowa ksiega przysłów i wyrażeń przysłowiowych polskich, t. I-IV, Warszawa 1969-1978. 
OrŁoś T. Z., 1994, Polskie i czeskie związki frazeologiczne z nazwami narodowości lub z przymiotnikami odnarodowościowymi, [w:] M. Basaj, D. Rytel (red.), „Z problemów frazeologii polskiej i słowiańskiej" VI, s. 139-153.

Pająкоwsка-Kensik M., 2009, Powiedzónka, [w:] M. Pająkowska-Kensik (red.), Nie tylko popularny słownik kociewski. Co o kulturze i przyrodzie regionu warto a nawet trzeba wiedzieć, Gruczno - Świecie, s. 137-145.

Pelletier C., 1998, Stereotyp Niemca i Anglika we Francji a w Polsce, [w:] J. Bartmiński, R. Tokarski (red.), Profilowanie w języku i w tekście, Lublin, s. 237-247.

S: B. Sychta, Słownik gwar kaszubskich na tle kultury ludowej, t. I-VII, Wrocław - Warszawa Kraków (- Gdańsk) 1967-1976.

SSWG: Zespół pod kier. M. Milaniak i E. Widy, Słownik spiskich wyrazów gwarowych, Łapsze Niżne 2006.

Szarota T., 1996, Niemcy i Polacy. Wzajemne postrzeganie i stereotypy, Warszawa.

Szerszunowicz J., 2004, Paralelizmy frazeologiczne $w$ analizie komparatywnej, „Białostockie

Archiwum Językowe" 4, s. 207-220.

Treder J., 1996, Kaszubska i pomorska frazeologia pochodzenia niemieckiego (na tle słowiańskim), [w:] A. M. Lewicki (red.), „Problemy frazeologii europejskiej” I, s. 131-146.

Tyrpa A., 2011, Cudzoziemcy i obce kraje w dialektach polskich, Kraków.

Tyrpa A., Zieliński L., 2003, Parallels in the Semantic Development of Ethnonyms in European Languages, [w:] Abstracts of Scholary Papers. Thesen der Vorträge. Résumés des communir cations. Тезисы докладов, Riga 2003, s. 109-110.

\section{Ethnic stereotypes in different languages: national? international? universal? Summary}

The paper discusses ethnic stereotypes petrified in different languages and referring to other nations. According to some researchers, in the lexis and phraseology of a given language, certain units can be distinguished which are only limited to this language. The article collects several examples from which it comes to light that when wider material is considered (including the history of a language, dialects and jargons), some lexemes and phrasemes are found to be present not in one, but in many languages. Analysis of numerous ethnic stereotypes in different languages reveals that transnational semantic patterns exist which are realized independently of linguistic affinity, e.g. in Indo-European as well as in Finno-Ugric languages. These patterns (models) contain slots for specific ethnonyms; how they are filled depends on extra-linguistic factors: historical experience, geographical neighbourhood, mutual friendly or hostile relations. The existence of petrified references to other nations in each language appears to be a universal feature. Specific realization of general semantic models is only partially studied. 